\title{
STATUS OF PRO- AND ANTICOAGULANT COMPONENTS OF HEMOSTASIS IN PATIENTS WITH STAGE VD CKD DEPENDING ON RESIDUAL RENAL FUNCTION
}

DOI: 10.36740/WLek202008125

\author{
Oleksiy B. Storozhuk², Iryna B. Seleznyova', Larysa A. Storozhuk', Tetyana V. Dovgalyuk', Borys G. Storozhuk², \\ Tetyana N. Platonova ${ }^{3}$ \\ 'RESEARCH INSTITUTE OF REHABILITATION OF NATIONAL PIROGOV MEMORIAL MEDICAL UNIVERSITY, VINNYTSIA, UKRAINE \\ ${ }^{2}$ NATIONAL PIROGOV MEMORIAL MEDICAL UNIVERSITY, VINNYTSIA, UKRAINE \\ 3PALLADIN INSTITUTE OF BIOCHEMISTRY OF NAS OF UKRAINE, KYIV, UKRAINE
}

\begin{abstract}
The aim: To study the status of pro- and anticoagulant components of hemostasis in patients with stage VD CKD depending on residual renal function. Materials and methods: 88 patients with stage VD CKD were studied, 16 of them had preserved residual renal function (RRF). Hemostatic parameters - soluble fibrin, D-dimer and protein C - were determined in the patients.

Results: Significant increase in soluble fibrin and fibrinogen levels along with depressive reaction of D-dimer and protein C were found in patients with stage VD CKD having lost RRF. Preserved RRF in those patients had positive influence on hemostatic profile, decreasing the degree of hypercoagulation.

Conclusions: 1. In long term dialysis patients with stage VD CKD and lost RRF, significantly increased levels in soluble fibrin and fibrinogen along with decreased D-dimer concentration were found, being a key factor in the development of thrombotic complications. 2. There was significant decrease in protein C activity in patients with lost RRF. 3. Preserved RRF in patients with stage VD CKD had positive influence on hemostatic profile.
\end{abstract}

KEY WORDS: hemostasis, chronic kidney disease (CKD), residual renal function (RRF)

Wiad Lek. 2020;73(8):1723-1725

\section{INTRODUCTION}

The terminal stage of CKD in general, and in cases of long term hemodialysis in particular, can adversely affect the status of various components of hemostasis and induce thrombogenesis. This is because kidneys are involved in production of anticoagulant factors (heparin), fibrinolytic factors (urokinase, tissue plasminogen activator), and procoagulant factors (thromboplastin, coagulation factors VII,VIII, IX, X), as well as in catabolism of coagulation factors (coagulation factor XII, fibrinogen) [1]. The process of secondary hemostatic system disturbances are greatly influenced by causes of CKD development, e.g. glomerulonephritis, hemodialysis procedure itself, as well as preserved or lost residual renal function $[1,2]$.

Thrombosis development is known to be the major complication in patients with stage V CKD, undergoing long term hemodialysis [1], although the relationship between hemostatic profile and RRF in such patients is underestimated. At the same time, RRF is an important factor influencing morbidity and mortality in hemodialysis patients $[3,4]$. Preserved residual renal function proved to be associated with decreased risk of complications and better survival [5].

Fibrinogen is well known to be the major enzyme of coagulation system, and activation of coagulation system leads to conversion of fibrinogen to fibrin with its subsequent degradation by plasmin. Soluble fibrin and D-dimer are molecular markers of those processes $[6,7]$, while protein $C$ is a natural coagulation inhibitor [8]. Hence, determination of those biochemical parameters of hemostasis is supposed to be helpful in providing comprehensive characteristics of hemostatic changes in such patients.

\section{THE AIM}

To study the status of pro- and anticoagulant components of hemostasis in patients with stage VD CKD, undergoing long term hemodialysis, depending on residual renal function.

\section{MATERIALS AND METHODS}

88 patients with stage VD CKD were studied (52 males and 36 females), 16 subjects (18.2\%) having preserved RRF (diurnal diuresis 500-1300 ml).

To estimate the marker of coagulation system activation - soluble fibrin in blood plasma, - we used two-site enzyme-linked immune-sorbent assay for quantitation of products formed after degradation of fibrin by plasmin. Monoclonal antibodies III-3b were used as "catch"-an- 
Table I. Hemostatic profile in patients with stage VD CKD having preserved and lost RRF.

\begin{tabular}{|c|c|c|c|c|c|}
\hline \multirow[t]{2}{*}{ No } & \multirow[t]{2}{*}{$\begin{array}{l}\text { Hemostasis } \\
\text { parameters }\end{array}$} & $\begin{array}{c}\text { Control group } \\
(n=20) \\
\text { (donors) }\end{array}$ & $\begin{array}{c}\text { Patients with } \\
\text { preserved RRF } \\
(n=16)\end{array}$ & $\begin{array}{l}\text { Patients with lost RRF } \\
(\mathrm{n}=72)\end{array}$ & \multirow[t]{2}{*}{$\mathbf{P}$} \\
\hline & & I & II & III & \\
\hline 1 & $\begin{array}{l}\text { Soluble fibrin } \\
\qquad(\mu \mathrm{g} / \mathrm{ml})\end{array}$ & $2.60 \pm 0.37$ & $2.96 \pm 0.19$ & $3.54 \pm 0.14$ & $\begin{array}{l}\text { PI-II }>0.05 \\
\text { PI-III }<0.02 \\
\text { PII-III }<0.02\end{array}$ \\
\hline 2 & $\begin{array}{l}\text { D-dimer } \\
(\mathrm{pg} / \mathrm{ml})\end{array}$ & $95.0 \pm 32.0$ & $50.63 \pm 7.01$ & $75.95 \pm 10.35$ & $\begin{array}{l}\text { PI-II }>0.05 \\
\text { PI-III }>0.05 \\
\text { PII-III }<0.05\end{array}$ \\
\hline 3 & $\begin{array}{l}\text { Fibrinogen } \\
(\mathrm{mg} / \mathrm{ml})\end{array}$ & $2.20 \pm 0.36$ & $3.41 \pm 0.14$ & $4.15 \pm 0.12$ & $\begin{array}{l}\text { PI-II }<0.002 \\
\text { PI-III }<0.001 \\
\text { PII-III }<0.001\end{array}$ \\
\hline 4 & $\begin{array}{l}\text { Protein C } \\
(\%)\end{array}$ & $100 \pm 10.0$ & $86.13 \pm 3.05$ & $80.05 \pm 1.47$ & $\begin{array}{l}\text { PI-II >0.10 } \\
\text { PI-III }<0.05 \\
\text { PII-III >0.05 }\end{array}$ \\
\hline
\end{tabular}

tibodies, and monoclonal antibodies II-4d - as "tag" antibodies [6]. D-dimer was estimated by enzyme immunoassay using monoclonal antibodies to D-dimer epitopes, which are formed after degradation of unsoluble fibrin by plasmin [7]. Protein C level was estimated using spectrophotometry (\%) by its activity in blood plasma, the activation being performed with copperhead snake venom (Agkistrodon halys halys) [8]. Fibrinogen level in blood plasma was estimated using thrombin-like enzyme Antsistron-H by spectrophotometry [9].

Statistical analysis of study findings was performed by the methods of variation statistics.

\section{RESULTS AND DISCUSSION}

According to study results, patients with stage VD CKD and lost RRF demonstrated significant $(\mathrm{p}<0.02)$ increase of soluble fibrin level compared to the control group and subjects with preserved RRF, being $3.54 \pm 0.14 \mu \mathrm{g} / \mathrm{ml}$ (Table I). By contrast, those with preserved RRF showed the increasing tendency in soluble fibrin level values as compared to the control group, being $2.96 \pm 0.19 \mu \mathrm{g} / \mathrm{ml}$ $(\mathrm{p}>0.05)$. It should be noted, that decreasing tendency in $\mathrm{D}$-dimer concentration was noted in both study groups as compared to controls, but patients with preserved RRF had significantly decreased D-dimer level as compared to those with lost RRF ( $\mathrm{p}>0.05$ ).

Low D-dimer levels along with increasing concentration of soluble fibrin, especially in subjects with lost RRF, was suggested to be due to depressive state of fibrinolysis, $\mathrm{D}$-dimer being its product as post-thrombosis indicator. It is noteworthy that concentration of fibrinogen appeared to be considerably increased in both groups of patients -1.5 times and twice, respectively, as compared to controls ( $\mathrm{p}<0.02 \div 0.001)$. At the same time, fibrinogen level in patients with lost RRF was significantly higher than that in subjects with preserved RRF ( $p<0.001)$. The values of anticoagulant protein C activity in patients with preserved RRF tended to de- cline, while they were significantly decreased in those with lost RRF ( $\mathrm{p}<0.05)$.

Assessment of correlation relationships between soluble fibrin and $\mathrm{D}$-dimer, fibrinogen and $\mathrm{C}$ protein in patients with lost RRF revealed direct relationship between soluble fibrin and $\mathrm{D}$-dimer, $(\mathrm{r}=0.56)$ and absence of correlation with fibrinogen $(r=0.04)$ and protein $C(r=-0.08)$. In subjects with preserved RRF, correlation relationships between soluble fibrin and D-dimer appeared to be weak $(r=0.29)$, it was moderate with fibrinogen $(r=0.34)$ and practically absent with protein $\mathrm{C}(\mathrm{r}=0.16)$. Those findings are indicative of inadequacy of fibrinolytic and anticoagulant components of hemostasis to increasing concentration of soluble fibrin in patients with stage VD CKD.

Due to considerable increase in blood plasma level of pre-thrombosis marker - soluble fibrin, high fibrinogen concentration with no corresponding adequate reaction of fibrinolytic component of hemostasis as well as low anticoagulant activity in patients with lost RRF, they are considered to have higher risk of thrombogenesis as compared to patients with preserved RRF.

Thus, preserved RRF have positive effect on hemostasis parameters, the latter may be partially explained by less negative effect of renin-angiotensin-aldosterone system on hypercoagulation processes in case of preserved RRF. Preservation of RRF is considered to be one of the primary goals in managing patients on long term hemodialysis to maximize their survival.

\section{CONCLUSIONS}

1. Long term dialysis patients with stage VD CKD and lost RRF, had significant decrease in levels of soluble fibrin and fibrinogen along with decreased D-dimer concentration, leading to thrombotic complications.

2. Protein $\mathrm{C}$ activity in patients with lost RRF was significantly decreased.

3. Preserved RRF in patients with stage VD CKD had positive effect on hemostasis parameters. 


\section{REFERENCES}

1. Mel'nik A.A. Sistema gemostaza i yeyo regulyatsiya pri narushenii funktsional'noy sosobnosti pochek [Hemostatic system and its regulation in kidney dysfunction]. News of Medicine and Pharmacy in Ukraine. 2016; 9(583):24-31. (In Russian).

2. Kolesnyk M.0., Zakon' K.M. Kardio-renal'nyy syndrom: novyy pidkhid do staroyi problemy [Cardio-renal syndrome: a new approach to the old problem]. Ukrainian Journal of Nephrology and Dialysis. 2009; 4(24):25-34. (In Ukrainian).

3. Bibkov B.T., Kirkhman V.V., Ushakova A.I. et al. Prediktory letal'nogo iskhoda u bol'nykh na gemodialize [Predictors of lethal outcome in patients with hemodialysis]. Nephrology and Dialysis. 2004; 2(6):154163. (In Russian).

4. Floege J., Kim J., Ireland E. et al. Serum iPTH, calcium and phosphate and the risk of mortality in a European haemodialysis population. Nephrol Dial Transplant. 2011;6(26):1948-1955.

5. Vasil'yeva I.A. Kachestvo zhizni bol'nykh s khronicheskoy pochechnoy nedostatochnost'yu [Quality of life in patients with chronic renal failure]. Nephrology. 2000; 1(7):26-40. (In Russian).

6. Komisarenko S.V., Luhovs'koy E.V., Kolesnikova I.M. et al. Patent № 69283, Ukrayina, MPK A61K 39/44 zayavl. 05.10.11; opubl. 25.04.12, Byul. № 8. Test systema imunofermentna dlya kil'kisnoho vyznachennya rozchynnoho fibrynu v plazmi krovi lyudyny [Immune-enzyme testsystem for quantitative estimation of soluble fibrin in human plasma]. (In Ukrainian).

7. Komisarenko SV, Lugovskoy EV, Kolesnikova IM et al. Patent № 69284. Ukrayina, MPK A61K 39/4 zayavl. 05.10.11; opubl. 25.04.12, Byul. № 8. Test systema imunofermentna dlya kil'kisnoho vyznachennya D-dymeru v plazmi krovi lyudyny [Immune-enzyme test-system for quantitative estimation of D-dimer in human plasma]. (In Ukrainian).

8. Gornitskaya 0.V., Platonova T.N. Vydeleniye i svoystva aktivatora proteina $S$ iz yada shchitomordnika obyknovennogo (Agkistrodon halys halys) [Selection and properties of the protein ( activator from copperhead snake venom (Agkistrodon halys halys)]. Biomedical Chemistry. 2003; 5(49):470-478. (In Russian).

9. Platonova T.N., Zaichko N.V., Chernyshenko T.M. et al. Otsenka informativnosti i prognosticheskoy znachimosti traditsionnykh skriningovykh i dopolnitel'nykh laboratornikh testov dlya diagnostiki trombofilii [Evaluation of informative and predictive value of traditional screening and additional laboratory tests for diagnosis of thrombophilia]. Laboratory Diagnostics. 2010; 4(54):3-10. (In Russian).
The study was conducted within the framework of the research "To determine the role of pro- and anticoagulant hemostasis factors and parameters of coagulation potential in the development of comorbid states in patients with $V D$ stage of chronic kidney disease and to elaborate the criteria for prophylaxis of thrombophilia", state registration No $0119 U 101156$.

\section{Conflict of interest:}

The Authors declare no conflict of interest.

\section{ORCID and contributionship:}

Oleksiy B. Storozhuk: 000-0003-4400-4719 A,B,D

Iryna B. Seleznyova: 0000-0002-5649-2775 ${ }^{E}$

Larysa A. Storozhuk: 0000-0002-4591-9534 ${ }^{B}$

Tetyana V. Dovgalyuk: 0000-0003-1614-9021 ${ }^{F}$

Borys G. Storozhuk: 000-0002-9590-2159 C,D

Tetyana N. Platonova: 0000-0002-7241-1146 E,F

\section{CORRESPONDING AUTHOR Tetyana V. Dovgalyuk \\ Research Institute of Rehabilitation \\ of National Pirogov Memorial Medical University \\ 26 Kosmonavtiv ave., 21021 Vinnytsia, Ukraine \\ tel: 050-063-6522 \\ e-mail:postboxt05@gmail.com}

Received: 10.09 .2019

Accepted: 08.06 .2020

A - Work concept and design, B - Data collection and analysis, C - Responsibility for statistical analysis,

D -Writing the article, $\mathbf{E}$-Critical review, $\mathbf{F}$ - Final approval of the article 